\title{
Cellulose-degrading enzymes from Aspergillus terreus D34 and enzymatic saccharification of mild-alkali and dilute-acid pretreated lignocellulosic biomass residues
}

\author{
Adepu K Kumar ${ }^{*}$ and Bhumika S Parikh
}

\begin{abstract}
Background: Production of cellulose-degrading enzymes from Aspergillus terreus D34 using different growth substrates was studied under solid-state cultivation. We have tested two lignocellulosic biomass residues viz., rice straw (RS) and sugarcane bagasse (BG), both separately and in combinations, and crystalline cellulose as a sole source of carbon for cellulase production. We also demonstrated different cellulase cocktail formulations and enzymatic saccharification studies on mild-alkali and dilute-acid pretreated RS- and BG-biomass residues.

Results: Substrate-specific non-denaturing native gels showed two exoglucanases, four endoglucanases, three $\beta$-glucosidases, and four xylanases in the microbial culture extract of RS-grown cells. While in the BG-culture extract, two exoglucanases, five endoglucanases, three $\beta$-glucosidases, and four xylanases were detected. Similarly, in crystalline cellulose-grown culture extract, three exoglucanases, four endoglucanases, one $\beta$-glucosidase, and two xylanases were detected. However, the cellulase compositions were highly varied with the culture extracts obtained from the mixed biomass (RSBG) growth substrate. We found that few enzymes were specifically induced while others were repressed in RSBG-grown cultures. Enzymatic saccharification resulted in the production of maximum reducing sugars of 0.733 and $0.498 \mathrm{~g} \mathrm{~g}^{-1}$ with mild-alkali treated RS- and BG-biomass residues with saccharification yields reaching up to $82.8 \% \pm 1.0 \%$ and $59.3 \% \pm 1.7 \%$, respectively.

Conclusions: The cellulase activities, namely FPase, CMCase, avicelase, $\beta$-glucosidase, and endoxylanase, were significantly higher in the BG-grown culture extract. Optimization of microbial growth carbon sources produced an efficient cellulase enzyme cocktail mixture with an approximately twofold higher total cellulase (FPase) activity that drastically reduced the required amount of enzyme (in terms of unit volumes) for enzymatic hydrolysis studies.
\end{abstract}

Keywords: A. terreus; Multiple expression; Cellulases; Lignocellulosic biomass; Saccharification

\section{Background}

Lignocellulosic plant biomass is the most abundant renewable bioenergy resource available on Earth. It will play a major role in the near future as an alternative bioresource to the currently existing non-renewable and exhaustive petroleum products for bioenergy applications. Globally, large quantities of agro-industrial wastes and crop residues are available in plenty and efficient utilization and microbial biodegradation of these biomaterials will lead to several

\footnotetext{
* Correspondence: kiranbio@gmail.com

Bioconversion Technology Division, Sardar Patel Renewable Energy Research Institute, Near BVM Engineering College, Vallabh Vidyanagar, Post box No. 2, 388120 Gujarat, India
}

processes of great economic value [1]. Particularly in Asian countries, surplus amounts of lignocellulosic residues are available annually without much usage, namely rice straw (667.6 million tons) and sugarcane bagasse (74.8 million tons). These could be used as a potential bioresource material for cellulosic ethanol production [2,3]. However, large amounts of these agricultural residues are still frequently burnt in the fields causing severe environmental pollution problems and may foresee in utilizing these biomass residues for various potential industrial applications, for example, production of microbial enzymes and liquid biofuels, etc.

\section{实 Springer}


The major components of lignocellulosic biomass residues are celluloses, hemicelluloses, and lignin. The cellulosic fractions could be broken down into simple reducing sugars either by enzymatic or chemical processes for fuel ethanol production [4,5]. A broad range of cellulolytic and hemicellulolytic enzymes belonging to the glycoside hydrolase $(\mathrm{GH})$ super family are produced by a variety of bacteria and fungi and are primarily involved in the breakdown of complex biomass residues into simple reducing sugars [6]. The major cellulase enzymes involved in lignocellulosic bioconversion processes are the following: (i) exoglucanases (1,4- $\beta$-cellobiohydrolase; avicelase; E.C: 3.2 .1 .4$)$ which act in a processive manner on the reducing and nonreducing ends of cellulose polysaccharide chains, liberating either cellobiose or glucose as major end products; (ii) endoglucanases (carboxymethyl cellulase; CMCase; E.C: 3.2.1.74) which randomly cut $\beta-1,4$ bonds of cellulose chains generating new ends; and (iii) $\beta$-glucosidases (E.C: 3.2.1.21) which specifically cut the cellobiose dimer units producing glucose monomers. Along with these enzymes, other key enzymes belonging to hemicellulases, mainly endoxylanases (E.C: 3.2.1.8), are known to act on the xylan portion of the biomass residue into pentoses, where xylan constitutes nearly $30 \%$ to $35 \%$ of total dry weight of the biomass.

Among several hypercellulolytic fungal strains, filamentous fungi such as Trichoderma and Aspergillus sps are considered as the major microbial sources for production of cellulose-degrading enzymes $[7,8]$. The genome sequencing of $T$. reesei revealed two cellobiohydrolases (CBHI and CBHII) and eight endoglucanases (EG) [9], among which only two major proteins (EGI and EGII) are usually secreted in notable quantities [10]. Trichoderma sps is a well-known commercial cellulase producer but lacks sufficient $\beta$-glucosidase activity in the enzyme mixture. Although up to $12 \beta$-glucosidases have been identified in $T$. reesei genome, most of them are found to be intracellular with low expression levels [9]. In contrary, Aspergillus sps produces high amounts of $\beta$-glucosidase in the extracellular medium and is commonly used for commercial production of this enzyme. A. terreus NIH 2624 genome is known, and it contains genes encoding 5 exoglucanases, 22 endoglucanases, $18 \beta$-glucosidases, and 7 xylanases and other genes with conserved domains that encode several putative cellulose-degrading enzymes and strongly establishes that multiple cellulase genes are present in A. terreus. Since expression of endoglucanases and cellobiohydrolases is very poor from Aspergillus sps, much research is focused towards $\beta$-glucosidase and xylanase production [11].

The process of lignocellulosic biomass bioconversion to ethanol involves three major steps, namely pretreatment, saccharification, and fermentation. Keeping in view of voluminous research reports on mild-alkali and dilute-acid pretreatments of lignocellulosic biomass residues and microbial fermentation processes [12-14], the detailed description on the two steps is not described in detail in this report and further researchers are suggested to refer recent reviews $[15,16]$. Saccharification of the pretreated lignocellulosic biomass depends mainly on the hydrolytic efficiency of each individual cellulase enzyme component present in the multi-cellulase complex and their synergistic action towards the breakdown of insoluble celluloses and hemicelluloses into simple reducing sugars [6]. In continuation to our earlier published work on the production of cellulases from $A$. terreus D34 and enzymatic hydrolysis on mild-alkali pretreated RS biomass [12,13], here we report the detailed zymographic identification studies of multiple cellulase hemicellulase enzymes and microbial growth substrate optimization for low-cost production of cellulases using cheap lignocellulosic biomass residues. In addition, enzymatic saccharification studies on mild-alkali and dilute-acid pretreated RS- and BG-biomass residues with different cellulase cocktails are also reported.

\section{Methods}

\section{Chemicals and raw materials}

Precut, washed, and dried RS- and BG-biomass residues and microcrystalline cellulose (Sigma-Aldrich, St. Louis, MO, USA) were used as substrates for microbial growth and cellulase production. Celluclast 1.5 L and Novozyme 188, Avicel, carboxymethyl cellulose (CMC), $p$-nitrophenyl- $\beta$-D-glucopyranoside (PNPG), 4-methylumbelliferyl- $\beta$-D-cellobioside (MUC), 4methylumbelliferyl- $\beta$-D-glucopyranoside (MUG), birchwood xylan, glucose, xylose, and cellobiose were purchased from Sigma-Aldrich (St. Louis, MO, USA) and were used for activity staining and enzyme assay measurements. The reagents for polyacrylamide gel electrophoresis (PAGE) analysis were purchased from Bio-Rad, Gurgaon, Haryana, India. All other chemicals and reagents were of analytical grade quality and were obtained from commercial sources.

\section{Lignocellulosic biomass preparation}

RS- and BG-biomass residues were procured from local agricultural fields and sugarcane refineries near Anand district, Gujarat. Initially, the biomass residues were extensively washed with water and then dried in sunlight for 3 to 4 days until the moisture content was reduced $<5 \%(w / w)$. The dried biomass residues were then cut into small size (5 to $10 \mathrm{~mm}$ ) using hammer mill. The precut biomasses were directly used without any further processing for microbial growth and enzyme production.

\section{Microbial culture and growth conditions}

We have recently reported the isolation of lignocellulosedegrading filamentous fungus $A$. terreus D34; microbial growth conditions and identification and complete details were given previously $[12,13]$. In brief, the filamentous 
fungus was grown for 7 days at $45^{\circ} \mathrm{C}$ on sterile agar slants comprising $2 \%(w / v)$ potato dextrose agar (PDA) and subcultured on fresh agar slants every 15 days. For long-term storage, spore suspensions were made in $0.1 \%(w / v)$ Triton $\mathrm{X}-100$ and then glycerol stock cultures were prepared and stored at $-80^{\circ} \mathrm{C}$ until further use.

\section{Enzyme production in solid-state cultivation}

Solid-state cultivation was carried out separately in $250 \mathrm{~mL}$ Erlenmeyer flasks containing RS- and BGbiomass residues and in combinations as a sole source of carbon for microbial growth. Crystalline cellulose was used as a synthetic growth substrate, and comparative analysis were performed with the naturally available lignocellulosic biomass residues. The RS to BG combinations tested were the following: 100:0, 25:75, 50:50, 75:25, and $0: 100$, where 100 correlate to $5 \mathrm{~g}$ dry weight of the respective biomass. All other growth parameters were maintained similar to our recent published report on cellulase production $[12,13]$. The incubated flasks were removed periodically every $24 \mathrm{~h}$ for 7 days, and enzyme activities and protein concentrations were measured.

\section{Crude cellulase extraction and ammonium sulfate precipitation}

The culture extract was separated from the microbial cells by the addition of $40 \mathrm{~mL}$ of $50 \mathrm{mM}$ sodium citrate buffer ( $\mathrm{pH} 4.8$ ) to the solid-state grown cells and incubated at $45^{\circ} \mathrm{C}$ for $1 \mathrm{~h}$ under mild stirring conditions (100 rpm) to remove loosely bound enzymes from the biomass residue. The solid residual slurry was separated by vacuum filtration, and then the filtrate was subjected to centrifugation at $10,000 \mathrm{xg}$ for $10 \mathrm{~min}$ for separation of the suspended particles. The so-obtained supernatant was further filtered through $0.45 \mu \mathrm{m}$ glass fiber filters under vacuum pressure (Millipore system, Millipore India Ltd, Bengaluru, Karnataka, India) to obtain a clear enzyme solution. Finally, the proteins in the clarified culture extract were subjected to ammonium sulfate precipitation $(85 \%$ to $90 \%(w / v))$, respectively. The precipitated proteins were resolubilized in $50 \mathrm{mM}$ sodium citrate buffer $(\mathrm{pH}$ 4.8) and then desalted in the above buffer by membrane dialysis (10 kDa cutoff) for 3 to $4 \mathrm{~h}$ with frequent buffer exchange. The desalted crude cellulases were used for enzymatic saccharification and zymographic experiments.

\section{Determination of cellulase activities}

Total cellulase activity (FPase) was measured by standard filter paper assay method following the NREL protocol [17]. In brief, $50 \mathrm{mg}$ of Whatman filter paper (grade I) incubated with $1 \mathrm{~mL}$ of diluted enzyme at pH 5.0 for $60 \mathrm{~min}$ at $50^{\circ} \mathrm{C}$. The concentration of reducing sugars formed was determined by dinitrosalicylic acid (DNSA) method [18].
Avicelase (exoglucanase) activity was measured by incubating $0.5 \mathrm{ml}$ of crude enzyme dilute with $2.5 \%(w / v)$ Avicel in $50 \mathrm{mM}$ citrate buffer (pH 5.0) for $60 \mathrm{~min}$ at $50^{\circ} \mathrm{C}$. One unit of FPase activity and avicelase activity is measured as the amount of enzyme required to release $1 \mu \mathrm{g}$ of glucose per min. Endoglucanase (CMCase) activity was measured by incubating $0.5 \mathrm{~mL}$ of diluted enzyme with $0.5 \mathrm{~mL}$ of $2 \%(w / v) \mathrm{CMC}$ in $50 \mathrm{mM}$ citrate buffer (pH 5.0) for $30 \mathrm{~min}$ at $50^{\circ} \mathrm{C}$. Finally, xylanase activity was measured by incubating $0.5 \mathrm{~mL}$ of diluted enzyme with $0.5 \mathrm{~mL}$ of $1 \%(w / v)$ birchwood xylan in $50 \mathrm{mM}$ citrate buffer (pH 5.0) for $30 \mathrm{~min}$ at $50^{\circ} \mathrm{C}$. The concentration of reducing sugars formed in the above assay experiments were determined as described above. The amount of enzyme required for liberating either $1 \mu \mathrm{g}$ of glucose or $1 \mu \mathrm{g}$ of xylose per minute under the above assay conditions was considered as one unit of CMCase or xylanase activity. $\beta$ Glucosidase assay was performed by incubating $0.2 \mathrm{~mL}$ of enzyme dilute and $0.2 \mathrm{~mL}$ of $0.01 \mathrm{M}$ PNPG and $1.6 \mathrm{~mL}$ of $50 \mathrm{mM}$ citrate buffer $\left(\mathrm{pH} \mathrm{5.0)}\right.$ ) for $30 \mathrm{~min}$ at $50^{\circ} \mathrm{C}$. Then, the reaction was stopped by the addition of $4 \mathrm{~mL}$ of $0.2 \mathrm{M}$ $\mathrm{NaOH}$-glycine buffer ( $\mathrm{pH}$ 10.6) [19]. The amount of enzyme required for liberating $1 \mu \mathrm{g}$ p-nitrophenol per minute was considered as one unit of $\beta$-glucosidase activity. All the assay experiments were carried out either voiding enzyme or substrate and were used as control. Enzyme activities were also determined for commercial enzymes (Celluclast 1.5 L and Novozyme 188) following the similar method described above. FPase and endoglucanase activities were measured for Celluclast $1.5 \mathrm{~L}$, and $\beta$-glucosidase activity was measured for Novozyme 188. The mean values from triplicate experiments were calculated and presented here.

\section{Native PAGE for zymographic analysis}

Native PAGE using concentrated enzyme solution from RS-, BG-, and cellulose-grown culture extracts was performed. Zymogram analysis for the identification of avicelase, CMCase, xylanase, and $\beta$-glucosidase isoforms was done. CMCase and xylanase active protein bands were detected separately on a $10 \%(w / v)$ separating gel with $2 \%(w / v)$ CMC and $2 \%(w / v)$ birchwood xylan substrates, respectively. Congo red dye staining method was used for the detection of zone of clearance by the enzymatic action of CMCase and xylanase proteins. Briefly, gel was loading with $30 \mu \mathrm{g}$ of crude enzyme sample obtained from RS-, BG-, RSBG-, and cellulose-grown cells. After running electrophoresis, the gel was incubated in $50 \mathrm{mM}$ sodium citrate buffer $(\mathrm{pH} \mathrm{5.0)}$ for $60 \mathrm{~min}$ at $50^{\circ} \mathrm{C}$ and then stained with $0.1 \%(w / v)$ Congo red solution for $20 \mathrm{~min}$. The gels are washed with $1 \mathrm{M} \mathrm{NaCl}$ to visualize the clear bands corresponding to the cellulase and hemicellulase active proteins. The developed gels were visualized and digitally imaged using gel documentation 
system (G-BOX, Syngene, Bengaluru, Karnataka, India). Whereas, avicelase and $\beta$-glucosidase enzyme proteins were identified separately with post-incubation of the gel either with $10 \mathrm{mM}$ MUC or $10 \mathrm{mM}$ MUG for 15 to $60 \mathrm{~min}$ at $37^{\circ} \mathrm{C}$ and was then viewed directly under UV light using gel documentation system. It is to be noted that the highly active proteins were initially detected as a clear band as soon as the dye reagent was added and were turned into dark color immediately after addition of developing agent. Whereas, at this staining period the less active protein bands were detected as clear white bands against dark background. Based on the mobility of the protein bands on the gel, the different enzyme active bands were labeled separately on each gel from top to bottom.

\section{Pretreatment of lignocellulosic biomass residues}

Mild-alkali and dilute-acid pretreatments were performed separately with $0.2 \mathrm{~kg}$ of the respective dried biomass. Alkali pretreatments were done at room temperature with $0.5 \% \mathrm{NaOH}$ at a solid-to-liquid ratio of $1: 20$ for $24 \mathrm{~h}$ following the optimized conditions that was reported recently by us $[12,13]$, while acid pretreatments were conducted at $121^{\circ} \mathrm{C}$ for 10,30 , and $60 \mathrm{~min}$ by incubating the biomass residues with $1.5 \% \mathrm{H}_{2} \mathrm{SO}_{4}$ at a solid to liquid ratio of 1:10. After both pretreatments, the biomass residues were neutralized to $\mathrm{pH} 7.0$ and washed thoroughly with distilled water until the residual glucose concentrations were $<0.1 \mathrm{~g} \mathrm{~L}^{-1}$. The pretreated biomass residues were stored in air-tight containers and kept at $4^{\circ} \mathrm{C}$ until use.

\section{Enzymatic saccharification}

All the enzymatic hydrolysis experiments were performed at $10 \%(w / v)$ solid loading at $45^{\circ} \mathrm{C}$ for $48 \mathrm{~h}$ in $50 \mathrm{~mL}$ screwcapped bottles. Based on our recently reported enzyme optimization studies, an enzyme loading of $9 \mathrm{FPU} \mathrm{g}^{-1}$ was selected in the current investigation [12,13]. All other experimental parameters were similar as detailed previously, unless specified. Control experiments were performed voiding both substrate and enzyme in the reaction mixtures. Enzymatic saccharification was also performed using commercial enzymes at an enzyme loading of 9 FPU of Celluclast $1.5 \mathrm{~L}$ and $100 \mathrm{U}$ of Novozyme 188 per gram of pretreated biomass. After enzymatic saccharification, the liquefied fraction was separated and clarified from the residual biomass by filtration method using glass fiber membrane filters. Reducing sugars were analyzed by both HPLC and DNSA methods. Saccharification yields were calculated as described by Taniguchi [20].

\section{Enzyme formulation and cellulase cocktail preparation}

Before the experimental setup, the crude cellulases obtained from RS- and BG-grown cells were physically premixed to a final $9 \mathrm{FPU} \mathrm{g}^{-1}$ in a ratio of RS25:BG75, RS50: BG50, and RS75:BG25, respectively. Saccharification experiments were also performed with three different formulated cellulase enzyme cocktails. All other parameters of saccharification process were not altered and maintained similar as described in the above section.

\section{Analytical methods}

Protein concentration was determined using BSA as standard following the method described by Bradford [21]. The contents of cellulose, hemicellulose, and lignin in the untreated and pretreated biomass residues were determined following the method described by Goering and Van Soest [22]. All the assay experiments were carried out in triplicates, and the mean values are given. Statistical analysis of the enzyme activities and saccharification yields was performed using ANOVA software, and the significance of difference in each data was denoted in superscripts by special characters. All the data presented in this study were the mean of three or more experiments with a variation within $10 \%$.

\section{Results and discussion}

Aspergillus sps were reported to utilize a broad range of lignocellulosic biomass residues for microbial growth and production of cellulose-degrading enzymes [11]. Also, the cellulase enzymes produced from $A$. terreus were highly active at low $\mathrm{pH}$ conditions and thermotolerant; thus it is a potential microbial source for hyperproduction of a broad range of cellulases for cellulose breakdown, especially towards enzymatic saccharification processes and bioethanol production. These cellulase active proteins form a synergetic network of complex biochemical mechanisms.

\section{Microbial cellulase production}

The cellulase and hemicellulase enzyme activities in the tested growth carbon substrates were found to gradually increase with the incubation time and reached maximum on the 7th day. Similarly, secretion of extracellular soluble proteins was also linearly increased with the growth incubation time irrespective of growth carbon substrate, and maximum concentration of proteins were found in the BG- $\left(32.8 \pm 2.2 \mathrm{~g} \mathrm{~L}^{-1}\right)$, followed by RS$\left(22.9 \pm 1.8 \mathrm{~g} \mathrm{~L}^{-1}\right)$ and cellulose- $\left(20.2 \pm 1.3 \mathrm{~g} \mathrm{~L}^{-1}\right)$ grown cultures, respectively.

\section{Filter paper activity}

Total cellulase (FPase) activity (FPU g $\mathrm{g}^{-1}$ ) in the crude extract was found to be maximum in BG-grown culture $(5.74 \pm 0.3)$, followed by RS- $(4.62 \pm 0.4)$ and cellulose$(1.96 \pm 0.3)$ grown cultures, respectively (Figure 1). Nearly a threefold increase in FPase activity in BGgrown culture extract and approximately fivefold with the mixed (RS-BG) growth substrates were obtained when compared to cellulose-grown extract (Table 1). 


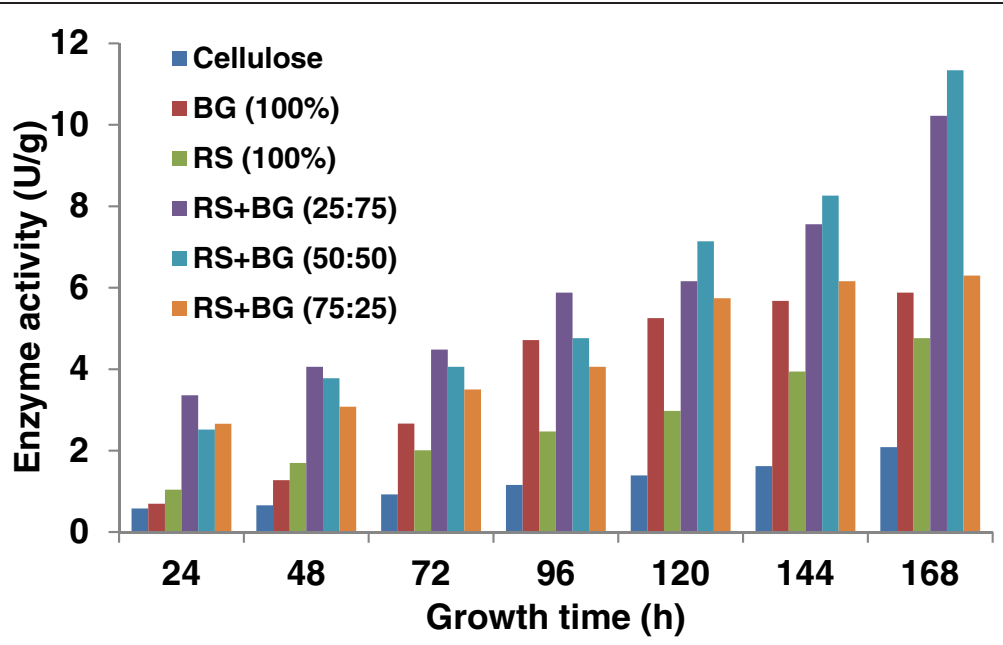

Figure 1 FPase activity from $A$. terreus during growth on rice straw (RS), bagasse (BG), and cellulose substrates.

The FPase activities in the culture extracts of the RS75: BG25-, RS50:BG50-, and RS25:BG75-mixed growth substrates were $6.3 \pm 1.1,11.34 \pm 0.7$, and $10.22 \pm 0.7$, respectively (Figure 1). Although the FPase activities were comparatively higher in the RS75:BG25 growth culture extract, higher $\mathrm{BG}$ content in the mixed growth substrate produced effective cellulase components in the enzyme cocktail that enhanced the total cellulase activity. Recently, it is reported that FPase activity of 1.02 and $3.2 \mathrm{U} \mathrm{ml}^{-1}$ was obtained with $A$. fumigates NIYDGPKA3 [23] and $A$. heteromorphus [24] using rice straw and wheat straw biomass residues as growth residues. The FPase activities presented in our study were significantly higher than other reports. A brief comparison was made with other reported cellulases and xylanases and their activities from Aspergillus strains and is given in Table 2.

\section{Cellobiohydrolase activity}

In similar to FPase, the exoglucanase (Ex) activities $\left(\mathrm{U} \mathrm{g}^{-1}\right)$ were also found to be maximum in the BG-grown culture $(10.5 \pm 0.3)$ with a twofold increase in enzyme activity followed by RS- $(6.86 \pm 0.3)$ and cellulose- $(5.32 \pm 0.3)$ grown cultures, respectively (Figure 2 ). However, with the mixed RS-BG growth substrates, the exoglucanase activities were comparable with the BG-grown culture. Whereas, in contrary to the findings on enzyme activities in different growth substrates, zymogram studies showed that cellulose substrate induced more number of exoglucanase proteins compared to BG- and RS-biomass substrates (Figure 3). In cellulose-grown culture, two high molecular proteins (Ex1 and Ex2) and one low molecular protein (Ex3) with exoglucanase activity were detected (Figure 3C). Whereas, Ex2 protein band in RS-grown culture and Ex3 protein band in BG-grown culture were not detected. Similar to RS-grown culture, both Ex1 and Ex3 protein bands were observed in RSBG-grown culture (Figure 3D). Among these protein bands, Ex1 protein showed high intensity in RS- and BGgrown culture extracts, while Ex3 in cellulose-grown culture was highly intense. Correlating both zymogram and enzyme activity analysis, it is clearly evident that majority of the exoglucanase activity might be associated with these high intense bands of their respective growth substrate. Detailed molecular and biochemical investigation on characterization of these individual exoglucanase active protein bands will provide further insight into the functional properties of the enzyme isoforms.

Table 1 Comparative analysis of cellulase and hemicellulase enzyme activities from $A$. terreus

\begin{tabular}{|c|c|c|c|c|c|c|}
\hline \multirow{2}{*}{$\begin{array}{l}\text { Enzyme activity } \\
\text { (U/g biomass) }\end{array}$} & \multicolumn{6}{|c|}{ Growth carbon substrate ${ }^{\#}$} \\
\hline & Cellulose & Sugarcane baggase & Rice straw & RS:BG (25:75) & $\mathrm{RS}: \mathrm{BG}(50: 50)$ & RS:BG (75:25) \\
\hline FPase & $1.96 \pm 0.3^{d}$ & $5.74 \pm 0.3^{b}$ & $4.62 \pm 0.4^{c}$ & $10.22 \pm 0.7^{\mathrm{a}}$ & $11.34 \pm 0.7^{\mathrm{a}}$ & $6.3 \pm 1.1^{b}$ \\
\hline Exoglucanase & $5.32 \pm 0.3^{h}$ & $10.5 \pm 0.3^{e}$ & $6.86 \pm 0.3^{9}$ & $8.4 \pm 0.8^{f}$ & $9.8 \pm 0.4^{e}$ & $10.22 \pm 0.5^{\mathrm{e}}$ \\
\hline Endoglucanase & $62.44 \pm 1.3^{n}$ & $145.32 \pm 2.5^{1}$ & $96.6 \pm 1.1^{\mathrm{m}}$ & $203.42 \pm 2.2^{j}$ & $213.22 \pm 0.3^{i}$ & $159.32 \pm 1.7^{k}$ \\
\hline$\beta$-Glucosidase & $13.72 \pm 0.3^{5}$ & $75.18 \pm 1.4^{\circ}$ & $74.9 \pm 1.7^{\circ}$ & $61.74 \pm 2.2^{r}$ & $69.14 \pm 1.5^{p}$ & $65.94 \pm 1.3^{9}$ \\
\hline Xylanase & $1,763 \pm 251^{x}$ & $8,472 \pm 490^{t}$ & $3,921 \pm 406^{w}$ & $7,280 \pm 462^{\mathrm{u}}$ & $6,959 \pm 252^{\mathrm{u}}$ & $6,050 \pm 294^{v}$ \\
\hline
\end{tabular}

Growth on rice straw (RS), sugarcane bagasse (BG), cellulose, and mixed RSBG carbon substrates.

"Each value represents the mean \pm standard error; values with no common alphabetic letter are significantly different at $p<0.05$. 
Table 2 Comparison of cellulase and xylanase production by some of the Aspergillus strains

\begin{tabular}{|c|c|c|c|c|c|c|c|}
\hline \multirow[t]{2}{*}{ Microorganism } & \multirow[t]{2}{*}{ Substrate } & \multicolumn{5}{|c|}{ Enzyme activity } & \multirow[t]{2}{*}{ Reference } \\
\hline & & FPase & Avicelase & CMCase & $\beta$-glucosidase & Xylanase & \\
\hline A. fumigatus NITDGPKA3 & Rice straw & $1.02 \mathrm{U} \mathrm{ml}^{-1}$ & - & $6.53 \mathrm{U} \mathrm{ml}^{-1}$ & $80.1 \mathrm{U} \mathrm{ml}^{-1}$ & $193.58 \mathrm{U} \mathrm{ml}^{-1}$ & [23] \\
\hline A. heteromorphus & Wheat straw & $3.2 \mathrm{U} \mathrm{ml}^{-1}$ & - & $83 \cup \mathrm{ml}^{-1}$ & - & - & {$[24]$} \\
\hline A. terreus strain EMOO 6-4 & Rice straw & - & - & - & $4,457 \cup \mathrm{g}^{-1}$ & - & {$[28]$} \\
\hline A. terreus RWY & Bagasse & $11.3 \cup \mathrm{g}^{-1}$ & $10.3 \cup^{-1}$ & $103 \cup g^{-1}$ & $122 \cup g^{-1}$ & $872 \cup g^{-1}$ & [29] \\
\hline A. niger & Bagasse & $153 \cup^{-1}$ & $67 \cup g^{-1}$ & - & - & - & {$[30]$} \\
\hline
\end{tabular}

\section{Endoglucanase activity}

The endoglucanase activity $\left(\mathrm{U} \mathrm{g}^{-1}\right)$ in BG-grown culture extract was significantly higher $(145.32 \pm 2.5)$ than the RS- $(96.6 \pm 1.1)$ and cellulose- $(62.44 \pm 1.3)$ grown cultures, respectively (Figure 4 ). The enzyme activities were approximately 1.5 - to 2-fold higher in BG compared to other growth carbon substrates. Similar to FPase, the endoglucanase activities were also increased in the all the RSBG-mixed growth cultures. The enzyme activities were $159.32 \pm 1.7,213.22 \pm 0.3$, and $203.42 \pm 2.2$ in RS75: BG25-, RS50:BG50-, and RS25:BG75-grown culture extracts, respectively (Figure 4). Jecu [25] also used mixed substrates (wheat straw and wheat bran) for cellulase production by $A$. niger; however, the endoglucanase activity was only $11.25 \mathrm{U} \mathrm{ml}^{-1}$, which is very low compared to our mixed growth substrates. Five endoglucanase proteins in BG- (Eg1, Eg2, Eg3, Eg5, and Eg6) and four each in cellulose- (Eg2, Eg3, Eg4, and Eg5) and RS- (Eg1, Eg2, Eg3 and Eg5) grown cultures, respectively, were detected by zymogram analyses (Figure 5). However, protein bands corresponding to Eg1 and Eg6 in cellulose-grown culture, Eg4 in BG- and RS-grown cultures and Eg4 and Eg5 in RSBG-grown cells, were not detected. These results indicate that BG induced production of additional endoglucanase proteins compared to RS-and cellulose-grown substrates. Sequential expression of multiple endoglucanase and $\beta$-glucosidase isoforms in different culture conditions and carbon sources was also recently reported in A. terreus; where, addition of fructose and cellobiose upregulated the endoglucanase activity while addition of mannitol, ethanol, and glycerol selectively repressed three endoglucanase isoforms [26]. Similarly, in Hypocrea jecorina, sophorose was reported to induce selective expression of endoglucanses and one xylanase isoform where xylobiose specifically induced xylanase I and xylanase II proteins [27].

\section{$\beta$-Glucosidase activity}

In contrary to the other cellulase activities, high $\beta$-glucosidase activity $\left(\mathrm{U} \mathrm{g}^{-1}\right)$ was obtained in both RS- and BGgrown culture extracts $(75.18 \pm 1.4)$ (Figure 6). Whereas, in cellulose-grown culture extract, negligible amount of $\beta$-glucosidase activity $(1.01 \pm 0.02)$ was observed, indicating that cellulose repressed production of $\beta$-glucosidase. Unlike other cellulase activities, $\beta$-glucosidase activities were not affected with the type of growth substrate. In RSBG-grown culture extracts, the enzyme activity was nearly similar $(69.14 \pm 1.5)$ in all the tested substrate ratios (Figure 6). Our results were in close comparison to A. fumigatus, where $80.1 \mathrm{U} \mathrm{ml}^{-1} \beta$-glucosidase was obtained [23]. Very recently, a newly isolated $A$. terreus strain EMOO 6-4 showed a maximum $\beta$-glucosidase activity of $4457.162 \mathrm{U} \mathrm{g} \mathrm{g}^{-1}$ using rice straw under

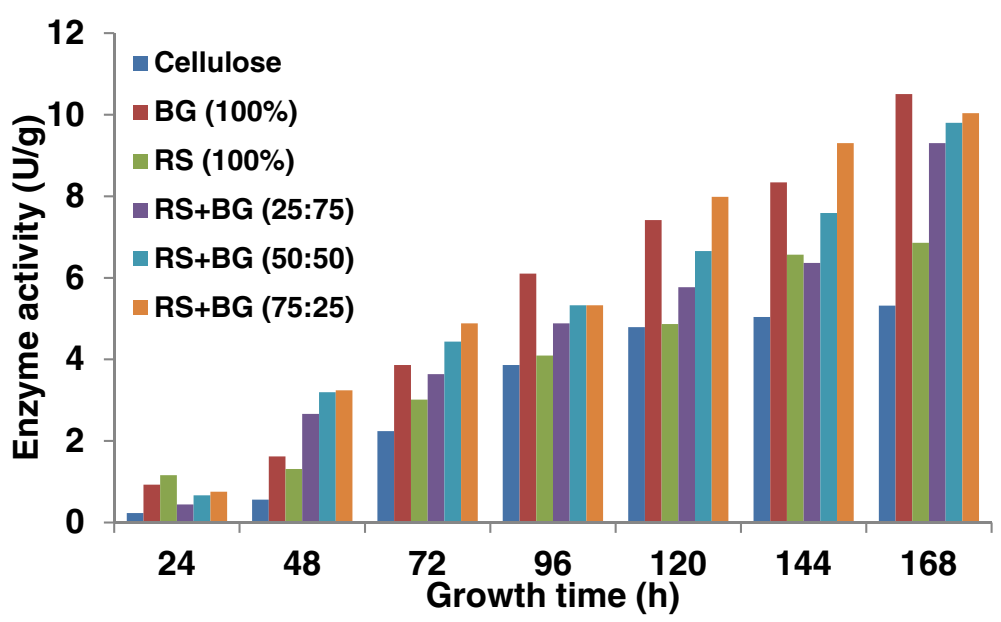

Figure 2 Exoglucanase activity from $A$. terreus during growth on rice straw (RS), bagasse (BG), and cellulose substrates. 


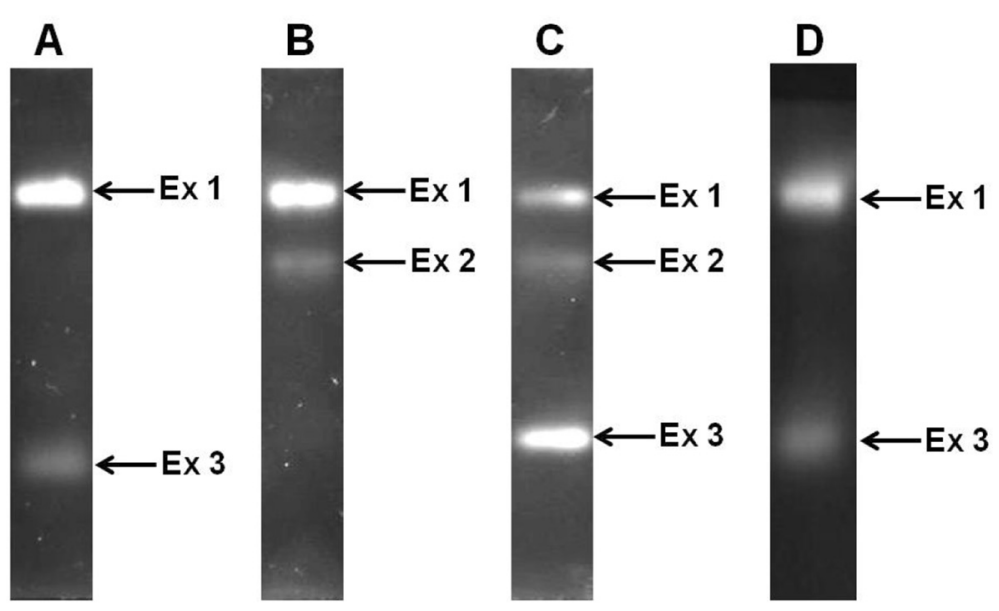

Figure 3 Detection of exoglucanases by zymogram analysis. Detection of exoglucanases by zymogram analysis using A. terreus crude cellulase cocktail produced from (A) rice straw-(RS), (B) sugarcane bagasse-(BG), (C) cellulose-, and (D) RS50:BG50-grown substrates.

statistically optimized growth conditions [28]. The enzyme activity results were also supported by the zymogram studies. A single broad protein band (Bg1) was detected in cellulose-grown cells, whereas, two additional proteins (Bg2 and $\mathrm{Bg} 3)$ were detected in BG- and only Bg3 in RS-grown culture extracts (Figure 7). Similar to RS-grown culture, RSBG-grown extracts produced only $\mathrm{Bg} 1$ and $\mathrm{Bg} 3$ proteins. Apparently, the slightly higher $\beta$-glucosidase activity in BG-grown extract could be correlated with the additional $\mathrm{Bg} 2$ protein. In contrary to the induction of endoglucanase expression in $A$. terreus; glucose, fructose, sucrose, cellobiose, mannitol, and glycerol addition also resulted in the repression of few $\beta$-glucosidase isoforms [26].

\section{Xylanase activity}

Xylanase activities $\left(\mathrm{U} \mathrm{g}^{-1}\right)$ in BG-grown culture extract $(8,472 \pm 490)$ was approximately twofold higher than the
RS-grown extracts $(3,921 \pm 406)$ and approximately fivefold higher than cellulose-grown extracts $(1,763 \pm 251)$ (Figure 8). Interestingly, the xylanase activities were increased linearly with the amount of BG content. The enzyme activities in RSBG-grown culture extracts were $6,050 \pm 294,6,959 \pm 252$, and 7,280 \pm 462 from RS75: BG25-, RS50:BG50-, and RS25:BG75-grown culture extracts, respectively (Figure 8). It is recently reported that a newly isolated $A$. terreus RWY produced xylanase activity of $872 \mathrm{U} \mathrm{g}^{-1}$ when sorghum bagasse was tested under solid-state conditions [29]. Significantly lower xylanase activity obtained from cellulose growth culture in correlation with the zymogram studies found that it could be due to the poor expression of xylanase active proteins. Only two xylanase proteins (Xy2 and $\mathrm{Xy} 3)$ were detected in cellulose growth culture extract while additional proteins viz. Xy1, Xy4, and Xy5 in RS- and Xy1 and $\mathrm{Xy} 5$ in BG-grown culture extracts were detected

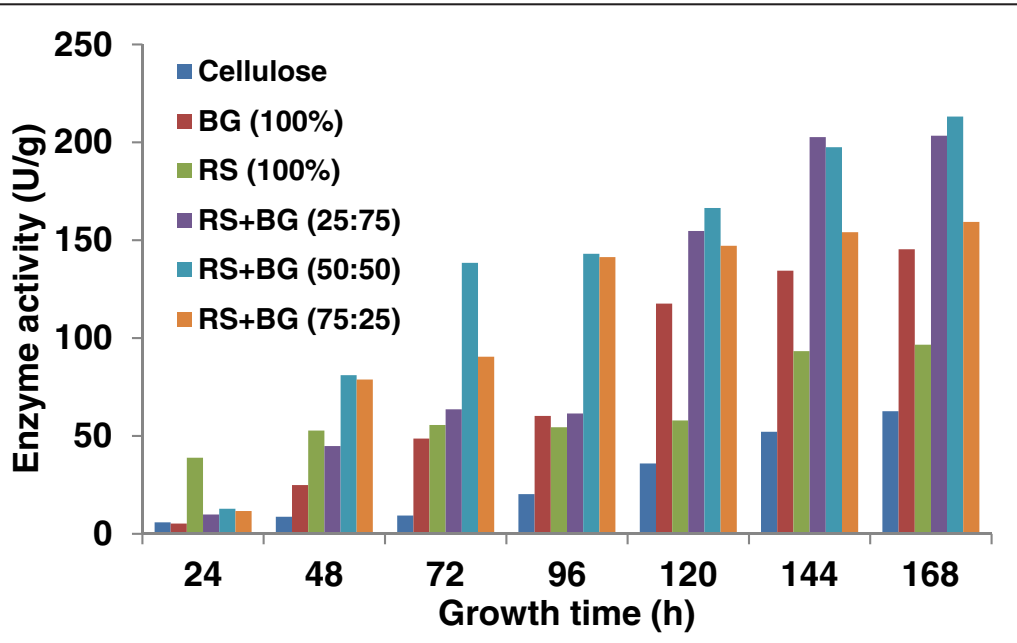

Figure 4 Endoglucanase activity from $A$. terreus during growth on rice straw (RS), bagasse (BG), and cellulose substrates. 

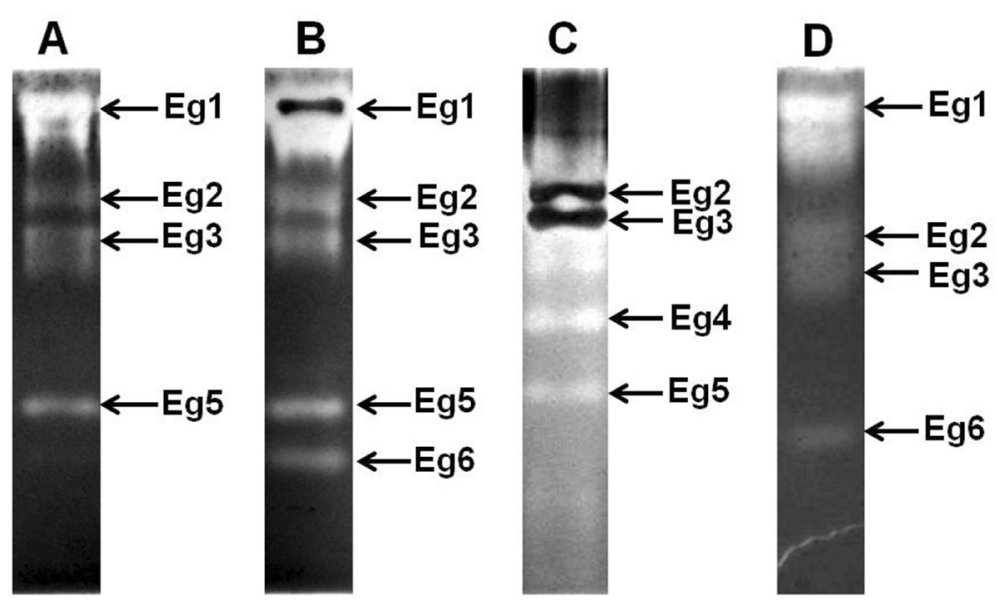

Figure 5 Detection of endoglucanases by zymogram analysis. Detection of endoglucanases by zymogram analysis using $A$. terreus crude cellulase cocktail produced from (A) rice straw-(RS), (B) sugarcane bagasse-(BG), (C) cellulose-, and (D) RS50:BG50-grown substrates.

(Figure 9). Although four xylanase proteins were detected in RS- and BG-grown extracts, however, a high molecular weight protein (Xy3) in RS-grown extract and a low molecular weight protein (Xy4) in BG-grown extract were not detected. In contrary to cellulase enzyme variants, all the xylanase enzymes were detected when RSBG-mixed growth culture extract was used in the growth medium (Figure 9D). From zymogram analysis and xylanase assay activity measurements, we could infer that the low intense protein (Xy3) might be crucial for enhancing the overall xylanase activity in the BG-grown culture extract. Our results on the identification of various xylanases from RS-, BG-, cellulose-, and RSBGgrown culture extracts also correlate with the earlier reports on the expression of distinct enzyme isoforms with the culturing conditions, where production of different multiple xylanases in Myceliopthora sps [31] and exoglucanases in A. niger [30] is detected.
From our results, it is clearly evident that the expression and repression of cellulase and hemicellulase genes in $A$. terreus D34 varied with the type of growth carbon source. This may be mostly due to the structural difference and architecture of the carbon source that play a crucial role in differential expression of the cellulolytic enzymes [32]. In addition to the culture conditions, small molecules and metabolites were also found to affect the production of cellulase enzymes in microbes like Aspergillus sps [25,32]. However, it is not clearly understood how the expression of these multiple proteins is regulated at gene level and further detailed molecular and proteomic analysis will provide the mechanism on the metabolic role of cellbound regulatory proteins and the cell-substrate interactions. But to some extent, it was reported that the regulation of cellulases was mediated by induction and repression of the genes that control the expression of cellulose-degrading enzymes [33,34]. Such studies on

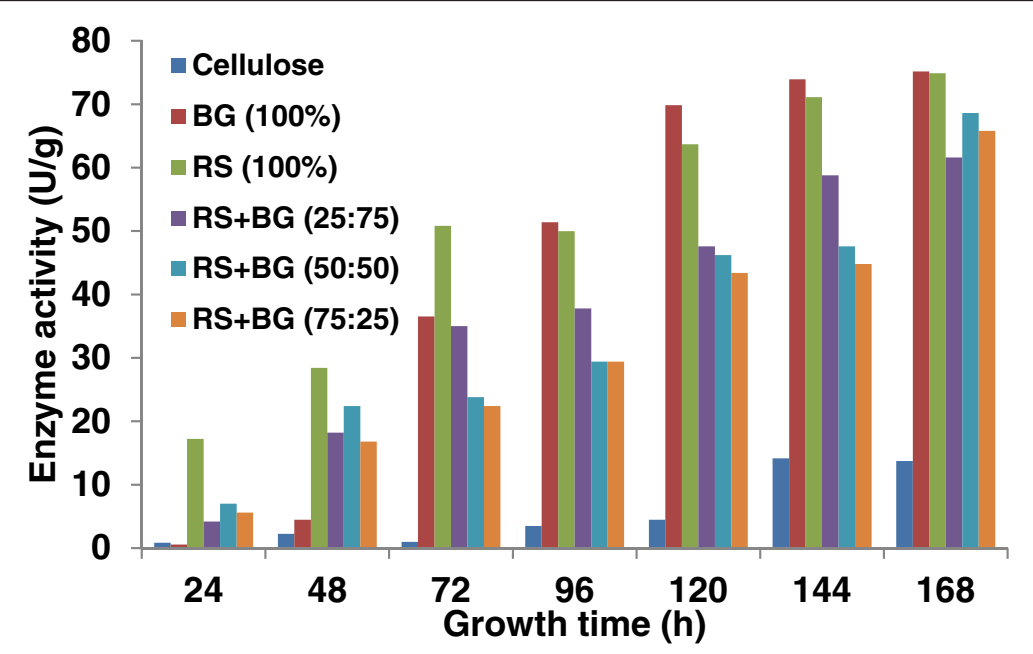

Figure $6 \beta$-Glucosidase activity from $A$. terreus during growth on rice straw (RS), bagasse (BG), and cellulose substrates. 


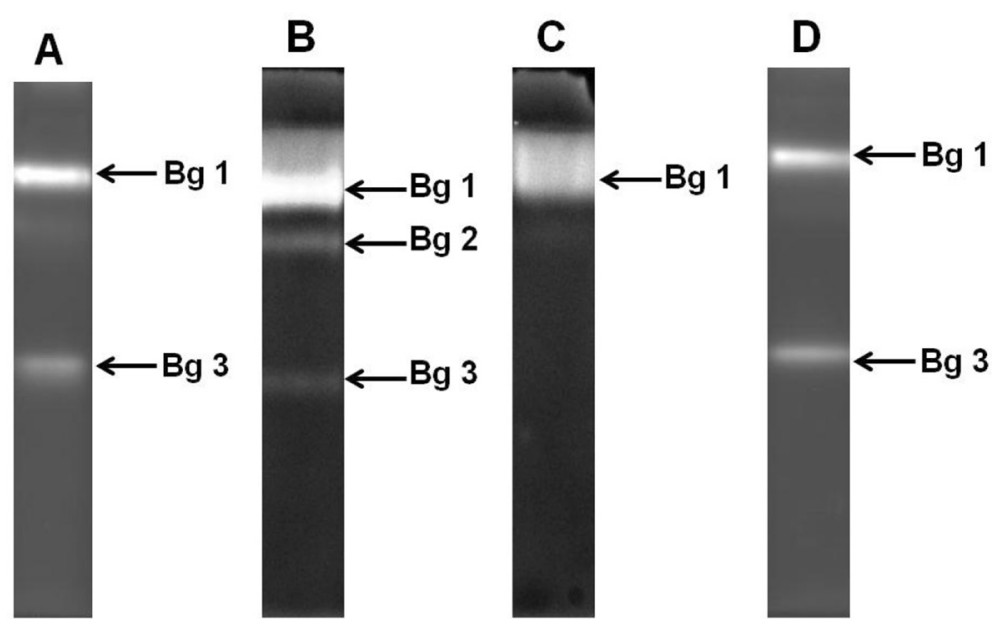

Figure 7 Detection of $\beta$-glucosidases by zymogram analysis. Detection of $\beta$-glucosidases by zymogram analysis using $A$. terreus crude cellulase cocktail produced from (A) rice straw-(RS), (B) sugarcane bagasse-(BG), (C) cellulose-, and (D) RS50:BG50-grown substrates.

multiple and differential expression of cellulase and hemicellulase enzymes and the corresponding enzyme activities in the culture extracts from different growth carbon substrates will produce an effective cellulase enzyme cocktail with all the cellulase enzyme components in a single mixture. The mechanism of expression and repression of each enzyme variant is under the control of a complex metabolic process, and this could be mostly due to the production and accumulation of various extracellular metabolites in the culture medium and their continuous interactions with the membrane transporter proteins [33]. Thus, it triggers the secretion of cellulose-degrading proteins into the extracellular medium during microbial growth on a specific lignocellulosic biomass residue [34]. For example, our experimental results showed nearly twofold higher xylanase activity in BG- than RS-biomass residues and may be correlated with high hemicellulose content present in the
BG biomass that may induce the secretion of additional xylanase active proteins. From zymogram and enzyme activity studies, the induction and repression of each enzyme variant and their probable correlation with the enzyme activities as discussed in this report strongly suggest the significant effect of biomass on the corresponding enzyme activities and was clearly demonstrated in Table 1. As shown in the case of exoglucanase, although Ex3 was not produced in BG-grown culture extract, the exoglucanase activity was significantly higher than the RS- and cellulosegrown extracts, indicating that the total exoglucanase activity was primarily from the Ex1 protein with no major contribution from Ex3 protein and was also clearly evident from the detection of a high intense sharp exoglucanase active protein band in zymographic analysis. Similarly, the role of Eg4 protein in endoglucanase activity could also support this inference. Moreover, the presence of $\mathrm{Bg} 3$

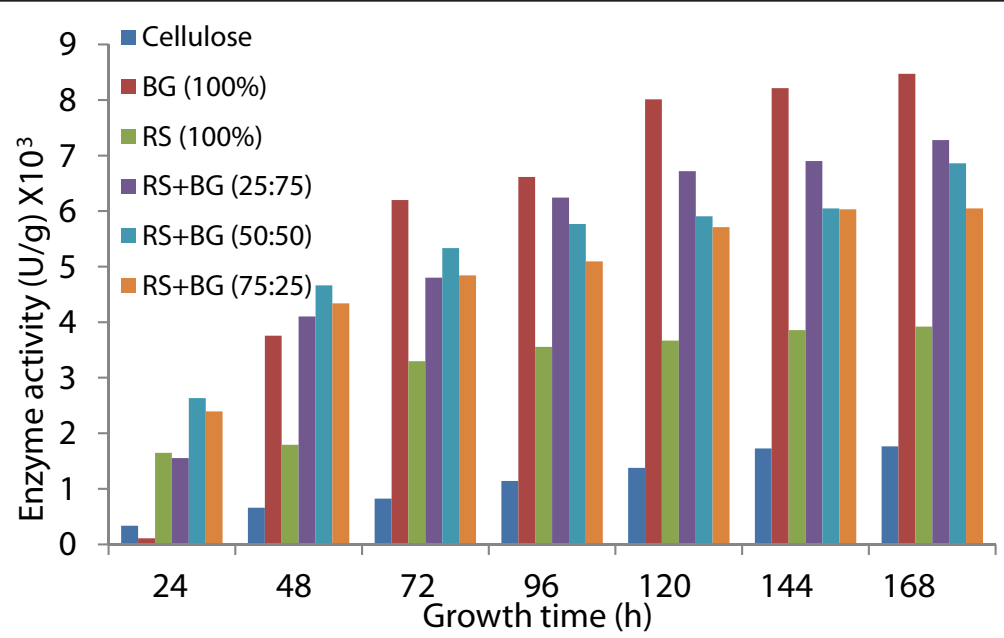

Figure 8 Xylanase activity from A. terreus during growth on rice straw (RS), bagasse (BG), and cellulose substrates. 

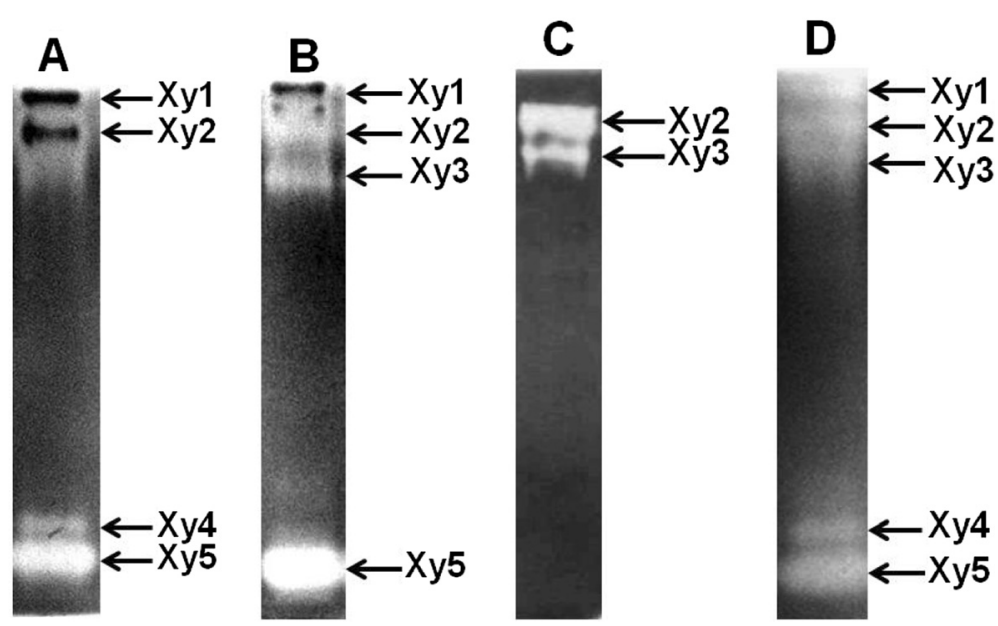

Figure 9 Detection of xylanases by zymogram analysis. Detection of xylanases by zymogram analysis using A. terreus crude cellulase cocktail produced from (A) rice straw-(RS), (B) sugarcane bagasse-(BG), (C) cellulose-, and (D) RS50:BG50-grown substrates.

protein is crucial for increased $\beta$-glucosidase activity. This conclusion was made on the observations with cellulose growth extract where $\mathrm{Bg} 3$ protein was not detected and a fourfold decrease in $\beta$-glucosidase activity was obtained. Also, the correlation data between xylanase activity and two low molecular xylanase isoforms (Xy4 and Xy5) strongly supports our results.

\section{Pretreatment of lignocellulosic biomass residues}

Delignification of RS biomass by mild-alkali pretreatment method increased the cellulose content from $40.0 \% \pm 1.8 \%$ to $60.1 \% \pm 1.2 \%$ with a marginal loss of hemicellulose content $(28.0 \% \pm 2.0 \%$ to $19.2 \% \pm 1.6 \%)$. The cellulose availability was slightly higher after mildalkali treatment. Interestingly, more than $70 \%$ of lignin was removed after mild-alkali pretreatment (Table 3). While after acid treatment, the holocellulose (mainly cellulose content) in the pretreated RS-biomass residue was increased to $76.8 \% \pm 1.1 \%$ with nearly complete removal of hemicellulose $(1.3 \% \pm 0.23 \%)$. Moreover, similar results were also obtained with BG biomass after both pretreatment methods. The cellulose content of BG after mild-alkali treatment was increased from $35.1 \% \pm 2.1 \%$ to $49.9 \% \pm 1.2 \%$ with hemicellulose content of $25.2 \% \pm 1.6 \%$. Although the holocellulose content was comparatively lower after acid pretreatment $(55.2 \% \pm 1.4 \%)$, similar to RS, the hemicelluloses $(1.6 \% \pm 0.9 \%)$ in BG were completely removed. Comparative amount of lignin was removed by mild-alkali treatment in the biomass residues while majority of the lignin content was retained after dilute-acid pretreatment (Table 3).

\section{Enzymatic hydrolysis of pretreated biomass}

Saccharification efficiency (\%) from mild-alkali pretreated RS-biomass residue was found to be $82.8 \pm 1.0$, $79.3 \pm 1.2$, and $73.0 \pm 2.0$ using crude concentrated cellulase mixture obtained from the RS-, BG-, and RSBGgrown culture extracts, respectively. With mild-alkali pretreated BG-biomass residue, the saccharification yields were comparatively lower $(37.1 \pm 2.1,52.4 \pm 1.9$, and $59.3 \pm 1.7$ ), where approximately $59 \%$ higher saccharification yields were obtained with enzyme obtained from RSBG culture extract. Similarly, with acid treated RS biomass, maximum reducing sugars were obtained with RSBG-grown culture extracts followed by RSgrown extract and vice versa when acid treated BG biomass was used for saccharification. However, with Celluclast $1.5 \mathrm{~L}$, the saccharification yields reached up to 93.3 \pm 0.7 and $82.1 \pm 0.4$ with mild-alkali treated RS- and BGbiomass residues and $52.9 \pm 0.5$ and $49.0 \pm 1.7$ were

Table 3 Compositional analysis of untreated and pretreated rice straw and sugarcane bagasse

\begin{tabular}{lllllcc}
\hline Biomass & Treatment & Residual straw (g) & Cellulose (\%) & Hemicellulose (\%) & Holocellulose (\%) & Lignin (\%) \\
\hline Rice straw & Untreated & 200 & $40.0 \pm 1.8$ & $28.0 \pm 2.0$ & $68.0 \pm 1.9$ & $9.0 \pm 0.8$ \\
& Alkali treated & 144 & $60.1 \pm 1.2$ & $19.2 \pm 1.6$ & $79.3 \pm 1.3$ & $3.5 \pm 0.6$ \\
& Acid treated & 110 & $76.8 \pm 1.1$ & $1.3 \pm 0.23$ & $78.1 \pm 0.8$ & $8.1 \pm 0.2$ \\
\multirow{2}{*}{ Sugarcane bagasse } & Untreated & 200 & $35.1 \pm 2.1$ & $31.2 \pm 1.7$ & $67.3 \pm 2.0$ & $19.2 \pm 0.4$ \\
& Alkali treated & 152 & $49.9 \pm 1.2$ & $25.2 \pm 1.6$ & $5.1 \pm 0.6$ & $10.6 \pm 1.3$ \\
& Acid treated & 125 & $49.6 \pm 2.5$ & $1.6 \pm 0.9$ & $52.2 \pm 1.4$ & $18.1 \pm 0.5$ \\
\hline
\end{tabular}


obtained with acid treated RS- and BG-biomass residues, respectively. While with mixed Celluclast $1.5 \mathrm{~L}$ and Novozyme 188, the saccharification yields reached maximum and were $96.5 \pm 0.3$ and $88.3 \pm 0.4$ with mild-alkali treated RS- and BG-biomass residues and $74.5 \pm 0.9$ and $54.2 \pm 1.0$ with acid treated RS- and BG-biomass residues, respectively. The synergetic affect of $\beta$-glucosidase in enhancing reducing sugar production from the pretreated biomass residues is clearly evident from these results. Moreover, the RS-grown culture extract enzyme produced reducing sugars which are nearly comparable with the commercial enzyme, Celluclast 1.5 L. Detailed reducing sugar concentrations and corresponding saccharification efficiencies of the respective pretreated biomasses and their enzyme sources were given in Table 4 . Interestingly, saccharification studies with the formulated enzyme cocktails showed slightly lower efficiencies for both alkali and acid treated biomass residues when compared with the crude cellulase enzymes from individual growth carbon sources (Additional file 1 Supplementary Table S1). With alkali treated RS- and BG-biomass residues, the maximum saccharification yields obtained with the formulated enzymes were $57.0 \pm 1.8$ and $42.5 \pm 1.7$, respectively. Whereas, with acid treated RS- and BG-biomass residues, the maximum saccharification yields were $44.2 \pm$ 1.4 and $21.5 \pm 1.9$, respectively. A comparison data of enzymatic hydrolysis of alkali and acid treated rice straw along with alkali and acid treated sugarcane bagasse was detailed in supplementary Table 2.

Beside zymogram studies of enzyme variants, interesting observations were made during this investigation and showed that nearly 1.25 - and 2.5 -fold increase in FPase, exoglucanase, endoglucanase, and xylanase activities were obtained with BG- and RS50:BG50-grown culture extracts when compared to RS-grown culture. Since these enzymes are known to be used in a wide variety of industrial applications, this may be an important factor to consider for large-scale production of enzymes and may significantly reduce the capital expenditures towards handling large capacity of biomass residues, reactor vessel volumes, and downstream processing costs, etc. [35]. However, for bioethanol production, the saccharification efficiencies with the isolated enzymes from RS-grown culture extracts were marginally higher

Table 4 Enzymatic saccharification of mild alkali and dilute acid pretreated lignocellulosic biomass residues

\begin{tabular}{|c|c|c|c|c|c|c|}
\hline \multirow{3}{*}{$\begin{array}{l}\text { Enzyme } \\
R S \text {-grown cells }\end{array}$} & \multirow{2}{*}{\multicolumn{2}{|c|}{$\begin{array}{l}\text { Pretreatment } \\
\text { condition }\end{array}$}} & \multicolumn{2}{|l|}{ Rice straw (RS) } & \multicolumn{2}{|l|}{ Sugarcane bagasse (BG) } \\
\hline & & & \multirow{2}{*}{$\begin{array}{l}\text { Reducing sugars }\left(\mathbf{g ~ g ~}^{-\mathbf{1}}\right) \\
0.621 \pm 0.013^{c}\end{array}$} & \multirow{2}{*}{$\begin{array}{l}\text { Saccharification (\%) } \\
70.2 \pm 1.5\end{array}$} & \multirow{2}{*}{$\begin{array}{l}\text { Reducing sugars }\left(\mathbf{g ~ g ~}^{-\mathbf{1}}\right) \\
0.249 \pm 0.016^{\mathrm{e}}\end{array}$} & \multirow{2}{*}{$\begin{array}{l}\text { Saccharification (\%) } \\
29.6 \pm 1.9\end{array}$} \\
\hline & Alkali & $24 \mathrm{~h}$ & & & & \\
\hline & & $48 \mathrm{~h}$ & $0.733 \pm 0.009^{9}$ & $82.8 \pm 1.0$ & $0.312 \pm 0.018^{j}$ & $37.1 \pm 2.1$ \\
\hline & Acid & $24 \mathrm{~h}$ & $0.356 \pm 0.015^{k}$ & $40.9 \pm 1.7$ & $0.179 \pm 0.011^{\mathrm{k}}$ & $30.8 \pm 1.9$ \\
\hline & & $48 \mathrm{~h}$ & $0.424 \pm 0.012^{p}$ & $48.8 \pm 1.4$ & $0.216 \pm 0.015^{p}$ & $37.2 \pm 2.6$ \\
\hline \multirow[t]{4}{*}{ BG-grown cells } & Alkali & $24 \mathrm{~h}$ & $0.648 \pm 0.008^{b}$ & $73.2 \pm 0.9$ & $0.336 \pm 0.021^{d}$ & $40.0 \pm 2.5$ \\
\hline & & $48 \mathrm{~h}$ & $0.702 \pm 0.011^{h}$ & $79.3 \pm 1.2$ & $0.440 \pm 0.016^{i}$ & $52.4 \pm 1.9$ \\
\hline & Acid & $24 \mathrm{~h}$ & $0.337 \pm 0.021^{1}$ & $38.8 \pm 2.4$ & $0.059 \pm 0.005^{m}$ & $10.3 \pm 0.9$ \\
\hline & & $48 \mathrm{~h}$ & $0.352 \pm 0.013^{q}$ & $40.5 \pm 1.5$ & $0.112 \pm 0.009^{9}$ & $19.3 \pm 1.5$ \\
\hline \multirow[t]{4}{*}{ Mixed growth cells (RS50:BG 50) } & Alkali & $24 \mathrm{~h}$ & $0.454 \pm 0.019^{d}$ & $51.3 \pm 2.1$ & $0.368 \pm 0.018^{c}$ & $43.8 \pm 2.1$ \\
\hline & & $48 \mathrm{~h}$ & $0.646 \pm 0.018^{i}$ & $73.0 \pm 2.0$ & $0.498 \pm 0.014^{h}$ & $59.3 \pm 1.7$ \\
\hline & Acid & $24 \mathrm{~h}$ & $0.293 \pm 0.012^{\mathrm{m}}$ & $33.7 \pm 1.4$ & $0.121 \pm 0.011^{1}$ & $20.8 \pm 1.9$ \\
\hline & & $48 \mathrm{~h}$ & $0.451 \pm 0.026^{\circ}$ & $51.9 \pm 3.0$ & $0.201 \pm 0.019^{p}$ & $34.6 \pm 3.3$ \\
\hline \multirow[t]{4}{*}{ Celluclast $1.5 \mathrm{~L}$} & Alkali & $24 \mathrm{~h}$ & $0.635 \pm 0.008^{b}$ & $71.8 \pm 0.9$ & $0.462 \pm 0.006^{b}$ & $55.0 \pm 0.7$ \\
\hline & & $48 \mathrm{~h}$ & $0.826 \pm 0.006^{f}$ & $93.3 \pm 0.7$ & $0.690 \pm 0.003^{9}$ & $82.1 \pm 0.4$ \\
\hline & Acid & $24 \mathrm{~h}$ & $0.285 \pm 0.010^{m}$ & $32.8 \pm 1.2$ & $0.105 \pm 0.004^{1}$ & $18.1 \pm 0.7$ \\
\hline & & $48 \mathrm{~h}$ & $0.460 \pm 0.004^{\circ}$ & $52.9 \pm 0.5$ & $0.285 \pm 0.010^{\circ}$ & $49.0 \pm 1.7$ \\
\hline \multirow[t]{4}{*}{ Celluclast $1.5 L+$ Novozyme 188} & Alkali & $24 \mathrm{~h}$ & $0.714 \pm 0.008^{\mathrm{a}}$ & $80.7 \pm 0.9$ & $0.513 \pm 0.008^{\mathrm{a}}$ & $61.0 \pm 1.0$ \\
\hline & & $48 \mathrm{~h}$ & $0.854 \pm 0.003^{e}$ & $96.5 \pm 0.3$ & $0.742 \pm 0.003^{f}$ & $88.3 \pm 0.4$ \\
\hline & Acid & $24 \mathrm{~h}$ & $0.420 \pm 0.012^{j}$ & $48.3 \pm 1.4$ & $0.168 \pm 0.011^{k}$ & $28.9 \pm 1.9$ \\
\hline & & $48 \mathrm{~h}$ & $0.648 \pm 0.008^{n}$ & $74.5 \pm 0.9$ & $0.315 \pm 0.006^{n}$ & $54.2 \pm 1.0$ \\
\hline
\end{tabular}

At $10 \%$ solid loading and enzyme loadings ${ }^{\#}$ of $9 \mathrm{FPU} / \mathrm{g}$ substrate using crude cellulase enzymes and formulated enzyme cocktails.

"Enzyme loadings of fixed concentration (9FPU/g substrate) for respective biomass were obtained directly from the crude enzyme from the respective biomass sources. In each case, the final enzyme loadings were calculated based on the enzyme activities shown in Table 1. Commercial enzymes (Celluclast $1.5 \mathrm{~L}$ and Novozyme 188) were also tested for comparison. Each value represents the mean \pm standard error; values with no common letter in a column (calculated separately for respective time, biomass, and pretreatment) are significantly different at $p<0.05$. 
compared to the RSBG-mixed growth culture extracts but at a fixed enzyme loading of 9 FPU/g biomass; the volume of protein required was significantly low (on the basis of respective enzyme activities shown in Table 1), where, in order to obtain the same enzyme loading, nearly twofold of the enzyme was required for RS-grown culture extract.

Similarly, most of the commercially available cellulase enzymes are formulated cocktails and there is a continuous thrust towards the development of efficient cellulase enzyme mixtures prepared by physical mixing of subtle amounts of other cellulose-degrading enzyme components for synergistic action and high product yields at low enzyme loadings. Formulation of cellulase enzyme activities for saccharification process will not only reduce the total enzyme loadings and but also decrease the capital expenditure costs (as described above) in a cellulosic biofuel production. Moreover, adding requisite amounts of enzyme components that were deficient in the cocktail mixture may further improve the overall process efficiency. It was clearly evident from the high saccharification yields of pretreated biomasses that using commercial enzymes were mainly attributed due to the external supplementation of $\beta$-glucosidase. All together, optimization of each enzyme component is attractive for lowering enzyme loadings; preparing such type of complex mixtures is quite challenging. Because it generally requires the separation of a particular enzyme component from the broth and re-addition into the cocktail which is considered to be one of the costly process [36], attempts were made to overcome such challenges in the preparation of formulated cellulase cocktails by physical mixing of crude enzymes and optimizing the growth carbon substrates, separately resulted in the production of an efficient enzyme mixture with at least twofold higher cellulase activities. Thus, it was concluded that crude cellulose-degrading enzymes produced by the $A$. terreus D34 with mixed growth substrates produced efficient crude enzyme mixture with the required enzyme components in appropriate proportions to yield high reducing sugars. These studies provide a clear evidence of the production of multiple cellulase proteins and their correlation with the corresponding enzyme activities with a complex synergetic mechanism for combined action between the enzyme components for effective lignocellulosic breakdown.

\section{Conclusion}

In the present study, we have demonstrated that during microbial growth, addition of BG-biomass residue to the RSbiomass residue enhanced the production of multiple cellulases and hemicellulases. Whereas, in RS-biomass residue and cellulose substrates, A. terreus was deficient in producing some cellulose-degrading enzymes that were found to be critical in increasing the overall enzyme activity. We further suggest that RSBG-mixed growth substrate could be a potential growth carbon source for cost-effective production of cellulases at a larger scale. Moreover, using RS-grown culture extract enzymes, saccharification yields of up to $82.8 \% \pm 1.0 \%$ were obtained from mild-alkali treated RS biomass and with mild-alkali treated BG biomass, up to $59.3 \% \pm 1.7 \%$ were obtained using RS50:BG50grown culture extract enzymes.

\section{Additional file}

Additional file 1: Table S1. Enzymatic saccharification of mild-alkali and dilute-acid pretreated lignocellulosic biomass residues at 10\% solid loading and enzyme loadings of $^{\prime}$ FPU/g substrate using crude cellulase enzymes and formulated enzyme cocktails.

\section{Competing interests}

The authors declare that they have no competing interests.

\section{Authors' contributions}

BSP performed the research experiments; AKK designed the research and wrote the paper. Both authors read and approved the final manuscript.

\section{Authors' information}

AKK, is a Senior Scientist and BSP is a Technical Assistant at the Sardar Patel Renewable Energy Research Institute, Bioconversion Technology Division, near BVM Engineering College, Vallabh Vidyanagar, Gujarat, India.

\section{Acknowledgements}

The authors are thankful to the Director, Sardar Patel Renewable Energy Research Institute, Gujarat, India, for the support of this research. The research work is financially supported by DBT, Govt. of India, through grant BT/PR10103/PBD/26/131/2007 and ICAR, Govt. of India. The authors acknowledge helpful discussions with Dr. S.P. Singh, SPRERI, and Prof. Datta Madambar, BRD School of Biosciences, Sardar Patel University, Gujarat, India.

Received: 25 November 2014 Accepted: 5 February 2015

Published online: 25 February 2015

\section{References}

1. Ray LG, Pal A, Ghosh A, Chattopadhyay P (1993) Cellulases and $\beta$-glucosidase from Aspergillus niger and saccharification of some cellulosic wastes. World J Micorbiol Biotechnol 8:85-94

2. Kim S, Dale BE (2004) Global potential bioethanol production from wasted crops and crop residues. Biomass Bioenergy 26:361-375

3. Yoswathana N, Phuriphipat P, Treyawutthiwat P, Eshtiaghi MN (2010) Bioethanol production from rice straw. Energy Res J 1:26-31

4. Margeot A, Hagerdal BH, Edlund M, Slade R, Monot F (2009) New improvements for lignocellulosic ethanol. Curr Opin Biotechnol 3:372-380

5. Sims RE, Mabee W, Saddler JN, Taylor M (2010) An overview of second generation biofuel technologies. Bioresour Technol 101:1570-80

6. Van Dyk JS, Pletchke BI (2012) A review of lignocelluloses bioconversion using enzymatic hydrolysis and synergistic cooperation between enzymes-factors affecting enzymes, conversion and synergy. Biotechnol Adv 30:1458-1480

7. Gusakov AV (2011) Alternatives to Trichoderma reesei in biofuel production. Cell 29:419-425

8. Zhang L, Wang X, Ruan Z, Liu Y, Niu X, Yue Z, Li Z, Liao W, Liu Y (2014) Fungal cellulase/xylanase production and corresponding hydrolysis using pretreated corn stover as substrates. Appl Biochem Biotechnol 172:1045-1054

9. Ouyang J, Yan M, Kong D, Xu L (2006) A complete protein pattern of cellulase and hemicellulase genes in the filamentous fungus Trichoderma reesei. Biotechnol J 1:1-9

10. Foreman PK, Brown D, Dankmeyer L, Dean R, Diener S, Dunn-Coleman NS, Goedegebuur F, Houfek TD, England GJ, Kelley AS, Meerman HJ, Mitchell T, Mitchinson C, Olivares HA, Teunissen PJM, Yao J, Ward M (2003) Transcriptional regulation of biomass degrading enzymes in the filamentous fungus Trichoderma reesei. J Biol Chem 278:31988-31997 
11. De Vries RP, Visser J (2001) Aspergillus enzymes involved in degradation of plant cell wall polysaccharides. Microb Mol Biol Rev 65:497-522

12. Narra M, Dixit G, Divecha J, Kumar AK, Madamwar D, Shah AR (2012) Production of cellulases by solid state fermentation with Aspergillus terreus and enzymatic hydrolysis of mild alkali-treated rice straw. Biores Technol 121:355-361

13. Narra M, Dixit G, Divecha J, Madamwar D, Shah AR (2013) Production, purification and characterization of a novel $\mathrm{GH} 12$ family endoglucanase from Aspergillus terreus and its application in enzymatic degradation of delignified rice straw. Int Biodeterior Biodegrad 88:150-161

14. Pietrobon VC, Monteiro RTR, Pompeu GB, Borges EP, Lopes ML, Amorim HV, Cruz SH, Viegas EKD (2011) Enzymatic hydrolysis of sugarcane bagasse pretreated with acid or alkali. Braz Arch Biol Technol 54:229-233

15. Chaturvedi V, Verma P (2013) An overview of key pretreatment processes employed for bioconversion of lignocellulosic biomass into biofuels and value added products. 3. Biotech 3:415-431

16. Mood SH, Golfeshan AH, Tabatabaei M, Jouzani GS, Najafi GH, Gholami M, Ardjmand M (2013) Lignocellulosic biomass to ethanol, a comprehensive review with a focus on pretreatment. Renew Sustain Energy Rev 27:77-93

17. Ghose T (1994) Measurement of cellulase activities. In: Commission on Biotechnology. IUPAC, New York, pp 1-12

18. Dashtban M, Maki M, Leung KT, Mao C, Qin W (2010) Cellulase activities in biomass conversion: measurement methods and comparison. Crit Rev Biotechnol 30:302-309

19. Kubicek CP (1982) Beta-glucosidase excretion by Trichoderma pseudokoningii: correlation with cell wall bound beta-1,3-glucanase activities. Arch Microbiol 132:349-354

20. Taniguchi M, Suzuki H, Watanabe D, Sakai K, Hoshino K, Tanaka T (2005) Evaluation of pretreatment with Pleurotus ostreatus for enzymatic hydrolysis of rice straw. J Biosci Bioeng 100:637-643

21. Bradford MM (1976) A rapid and sensitive method for the quantitation of microgram quantities of protein utilizing the principle of protein-dye binding. Anal Biochem 72:248-254

22. Goering HK, Van Soest PJ (1970) Forage fiber analysis (apparatus, reagents, procedures and some applications). In: USDA Agricultural Handbook No. 379, Washington

23. Sarkar N, Aikat K (2014) Aspergillus fumigatus NITDGPKA3 provides for increased cellulase production. Int J Chem Engg 2014:1-9

24. Singh A, Singh N, Bishnoi NR (2009) Production of cellulases by Aspergillus heteromorphus from wheat straw under submerged fermentation. Int J Environ Sci Engg 1:23-26

25. Jecu $L$ (2000) Solid state fermentation of agricultural wastes for endoglucanase production. Ind Crop Products 11:1-5

26. Nazir A, Soni R, Saini HS, Kaur A, Chadha BS (2010) Profiling differential expression of cellulases and metabolic footprints in Aspergillus terreus. Appl Biochem Biotechnol 162:538-547

27. Rauscher AJ, Wurleitner E, Wacenovsky C, Aro N, Stricker AR (2006) Transcriptional regulation of xyn1, encoding xylanase I in Hypocrea jecorina. Eukaryotic Cell 5:447-456

28. Ahmady NE, Naggar E (2015) Optimization of $\beta$-glucosidase production by Aspergillus terreus strain EMOO 6-4 using response surface methodology under solid state fermentation. Prep Biochem Biotechnol 45:568-587

29. Sharma R, Kocher GS, Bhogal RS, Oberoi HS (2014) Cellulolytic and xylanolytic enzymes from thermophilic Aspergillus terreus RWY. J Basic Microbiol 54:1367-1377

30. Hanif A, Yasmeen A, Rajoka MI (2004) Induction, production, repression and de-repression of exoglucanase synthesis in Aspergillus niger. Biores Technol 94:311-319

31. Badhan AK, Chadha BS, Kaur J, Saini HS, Bhat MK (2007) Production of multiple xylanolytic and cellulolytic enzymes by thermotolerant fungus Myceliophthora sp. IMI 387099. Biores Technol 98:504-510

32. Resch MG, Donohoe BS, Baker JO, Decker SR, Bayer EA, Beckham GT, Himmel ME (2013) Fungal cellulases and complex cellulosomal enzymes exhibit synergistic mechanism in cellulose deconstruction. Energy Environ Sci 6:1858-1867

33. Sanchez-Herrera LM, Ramos-Valdivia AC, Torrre M, Salgado LM, PonceNoyola T (2007) Differential expression of cellulases and xylanases by Cellulomonas flavigena grown on different carbon sources. Appl Microbiol Biotechnol 77:589-595
34. Messner R, Gruber F, Kubicek CP (1998) Differential regulation of synthesis of multiple forms of specific endoglucanases by Trichoderma reesei QM9414. J Bacteriol 170:3689-3693

35. Kuhad RC, Gupta R, Singh A (2011) Microbial cellulases and their industrial applications. Enz Res. doi:10.4061/2011/280696

36. Falls M, Shi J, Ebrik MA, Redmond T, Yang B, Wyman CE, Garlock R, Balan V, Dale BE, Pallapolu VR, Lee YY, Kim Y, Mosier NS, Ladisch MR, Hames B, Thomas S, Donohoe BS, Vinzant TB, Elander RT, Warner RE, Ramirez RS, Holtzapple MT (2011) Investigation of enzyme formulation on pretreated switchgrass. Biores Technol 102:11072-11079

\section{Submit your manuscript to a SpringerOpen ${ }^{\odot}$ journal and benefit from:}

- Convenient online submission

- Rigorous peer review

- Immediate publication on acceptance

- Open access: articles freely available online

- High visibility within the field

- Retaining the copyright to your article

Submit your next manuscript at $>$ springeropen.com 